\title{
Exploring alternative hapten tethering sites for high-affinity anti-picoxystrobin antibody generation
}

Javier Parra ${ }^{a, \S}$, Francesc A. Esteve-Turrillas ${ }^{a, \S}$, Antonio Abad-Somovilla ${ }^{b}$, Consuelo Agulló ${ }^{\mathrm{b}}$, Josep V. Mercader ${ }^{\mathrm{a},{ }^{*},}$, Antonio Abad-Fuentes ${ }^{\mathrm{a},{ }^{*}}$

a Department of Biotechnology, IATA-CSIC, Agustí Escardino 7, 46980 Paterna, València, Spain

${ }^{b}$ Department of Organic Chemistry, Universitat de València, Doctor Moliner 50, 46100 Burjassot, València, Spain

Authors' footnotes:

* Corresponding authors. Tel.: +34-963900022. Fax: +34-963636301. E-mail addresses: aabad@iata.csic.es (A. Abad-Fuentes) and jvmercader@iata.csic.es (J.V. Mercader).

$\S$ Both authors contributed equally to this work. 


\section{Abstract}

The relevance of the linker tethering site in haptens was investigated for antibody generation and immunoassay development. Three derivatives of the strobilurin fungicide picoxystrobin were synthesized with the same functionalized spacer arm located at three different positions. Protein conjugates of those haptens were employed as immunogens and novel polyclonal antibodies were produced and characterized. All haptens afforded highly specific antibodies, but different affinities to the free analyte were observed among the obtained antisera. Then, competitive enzyme-linked immunosorbent assays were studied in several formats, and site heterology was confirmed as an effective strategy for detectability improvement. An indirect heterologous immunoassay was eventually selected and optimized, showing a limit of detection for picoxystrobin of $0.02 \mu \mathrm{g} / \mathrm{L}$ and a working range between 0.03 and $1.30 \mu \mathrm{g} / \mathrm{L}$. Finally, the developed extraction and analytical procedures revealed a practical limit of quantification of $5 \mu \mathrm{g} / \mathrm{kg}$ for this fungicide in soybean sprouts, well below the maximum residue limits in the EU.

Keywords: Pesticide; Fungicide; Strobilurin; Hapten synthesis; Polyclonal antibody; ELISA; Immunoassay; Soybean analysis 


\section{Introduction}

Pesticide analysis is traditionally carried out by instrumental chromatographic separation methods. Alternatively, bioanalytical techniques such as the competitive immunoassays have been revealed as complementary tools for the analysis of chemical residues and contaminants in clinical, food, and environmental samples. Due to the haptenic character of such analytes they need to be coupled to a carrier protein in order to trigger an immunological response. Thus, preparing target derivatives is usually an essential requirement if the generation of high-quality antibodies is sought. A typical synthetic hapten consists of the target molecule and a linker arm containing a functional chemical group for carrier coupling. Therefore, accurate hapten design is a key step for the generation of highaffinity antibodies with the optimal selectivity. Several aspects are believed to influence the properties of the resulting antibodies; for instance, the position and composition of the linker and the preservation of the electronic and steric properties of the target molecule are among the most relevant constraints. However, the optimal parameters may change from one compound to another, so the preparation of a battery of functionalized haptens of the target analyte is certainly recommended. Moreover, the availability of different derivatives makes possible the development of enzyme-linked immunosorbent assays (ELISA) ${ }^{1}$, not only with protein conjugates carrying a homologous hapten (the same molecule that was used in the immunogen) but also using a heterologous one, which is a common strategy to improve immunoassay detectability [1,2]. Of all sorts of heterologies, site-heterology, based on a different tethering site of the spacer arm, has been demonstrated as a very promising strategy for achieving high-sensitivity ELISAs, mainly in polyclonal antibody-based assays $[3,4]$. 
Strobilurins are a new class of modern synthetic fungicides whose biological activity is due to a pharmacophore group similar to that of the natural active principle (strobilurin $A$ ) produced by the fungus Strobilurus tenacellus. These pesticides, as compared with other common fungicide groups, show a novel mode of action that is based on the inhibition of mitochondrial respiration by binding to cytochrome $b$ [5]. Among strobilurins, picoxystrobin (PC) shows a particular behavior because it is rapidly absorbed into the plant tissue and it is the most xylem-systemic of all members of this group. For that reason, it is targeted as an early-season application on cultures with preventive and curative purposes. PC can be transferred by air, so the product remaining at the outside of the leaf can be redistributed towards new emerging shoots [6]. This pesticide was approved in the EU in 2003 [7] and it has been registered at the US Environmental Protection Agency as a new chemical candidate [http://www.epa.gov/opprd001/workplan/newchem.html]. Nowadays, it is distributed by DuPont as a broad-spectrum fungicide for treatment of cereal grains and oilseed crops [http://www2.dupont.com].

Lately, a few papers have been published concerning the development of analytical strategies for PC determination, based on gas chromatography coupled to mass spectrometry or liquid chromatography with diode array detectors [8-10]. Besides, we recently produced an antibody to PC with an affinity value in the low nanomolar range [11]. That antibody was produced by immunization with a protein conjugate of a novel hapten molecule (hapten $\mathrm{PCa}$ ) prepared in our lab. This hapten incorporated a six-carbon spacer arm through a carbon-carbon single bond at the aryl ring of the molecule, in the para position with respect to the 6 -methoxyacrylate pharmacophore group (see Table 1 ). Now, two additional PC derivatives have been synthesized and new polyclonal antibodies (pAbs) have been generated by immunization of rabbits using immunogens of the three synthetic 
haptens in order to study the relationship between hapten derivatization site and antibody affinity. The objectives of the present study also comprised the development of immunoassays using the conjugate-coated indirect competitive ELISA (cELISA), the antibodycoated direct CELISA, and the capture-antibody direct CELISA formats, with both homologous and heterologous antigens. The most sensitive assay was fully characterized, optimized, and ultimately applied to the determination of PC residues in soybean sprouts as a relevant commodity for this fungicide.

\section{Materials and methods}

\section{Reagents and instrumentation}

Solvents and all other reagents used for hapten synthesis were obtained from commercial sources and employed without further purification. tert-Butyl 6-bromohexanoate (16) was obtained by esterification of 6-bromohexanoic acid with isobutene following a procedure previously described for the preparation of related tertbutyl esters [12]. 1-Bromo-2-(bromomethyl)benzene (7), tert-butyl hex-5-ynoate (9), and (Z)-methyl 2-iodo-3-methoxyacrylate (13) were obtained from 2-bromotoluene, hex-5-ynoic acid, and (E)-methyl 3-methoxypropenoate, respectively, according to published procedures [13-15]. Melting points were determined using a Kofler hot-stage apparatus and are uncorrected. NMR spectra were recorded in $\mathrm{CDCl}_{3}$ or $\mathrm{C}_{6} \mathrm{D}_{6}$ at room temperature (rt) on a Bruker AC-300 spectrometer (300.13 MHz for ${ }^{1} \mathrm{H}$ and $75.47 \mathrm{MHz}$ for $\left.{ }^{13} \mathrm{C}\right)$. The spectra were referenced to residual solvent protons in the ${ }^{1} \mathrm{H}$ NMR spectra (7.26 and $7.15 \mathrm{ppm}$ ) and to solvent carbons in the ${ }^{13} \mathrm{C}$ NMR spectra (77.0 and $128.02 \mathrm{ppm}$ ). Carbon substitution degrees were established by distortionless enhancement by polarization transfer pulse sequences. A combination of correlation spectroscopy and heteronuclear single quantum coherence 
experiments was utilized for the assignment of ${ }^{1} \mathrm{H}$ and ${ }^{13} \mathrm{C}$ chemical shifts. IR spectra were measured as $\mathrm{KBr}$ pellets or between $\mathrm{NaCl}$ plates using a Nicolet Avatar 320 spectrometer. MS and high resolution mass spectra (HRMS) were obtained by electron-impact (EI) at $70 \mathrm{eV}$ with a Micromass VG Autospec spectrometer. The reactions were monitored with the aid of thin-layer chromatography using $0.25 \mathrm{~mm}$ precoated silica gel plates. Chromatography refers to flash column chromatography and it was carried out with the indicated solvents on silica gel 60 (particle size $0.040-0.063 \mathrm{~mm}$ ).

Sephadex G-25 HiTrap Desalting columns from GE Healthcare (Uppsala, Sweden) were used for conjugate purification. Horseradish peroxidase (HRP), ovalbumin (OVA), and o-phenylenediamine were purchased from Sigma-Aldrich (Madrid, Spain). Polyclonal goat anti-rabbit immunoglobulin (GAR) was from Rockland (Gilbertsville, PA, USA). Polyclonal goat anti-rabbit immunoglobulin peroxidase conjugate (GAR-HRP) was from Bio-Rad (Madrid, Spain). Bovine serum albumin (BSA) fraction V was purchased from Roche Applied Science (Mannheim, Germany). Fetal bovine serum (FBS) and Freund's adjuvants were from Sigma-Aldrich (Madrid, Spain). Costar flat-bottom high-binding polystyrene ELISA plates were from Corning (Corning, NY, USA). Hapten and conjugate UV-vis spectra and ELISA absorbances were read in dual wavelength mode $(492-650 \mathrm{~nm})$ with a PowerWave HT from BioTek Instruments (Winooski, VT, USA). ELISA plates were washed with an ELx405 microplate washer also from BioTek Instruments.

PC (methyl (E)-3-methoxy-2-\{2-[6-(trifluoromethyl)-2-pyridyloxymethyl]phenyl\}acrylate, CAS Registry No. 117428-22-5, MW $367.32 \mathrm{~g} / \mathrm{mol}$ ) and other employed pesticide standards were purchased from Fluka/Riedel-de-Haën (Seelze, Germany) or Dr. Ehrenstorfer (Augsburg, Germany). Pesticide stock solutions were prepared as concentrated solutions in $\mathrm{N}, \mathrm{N}$-dimethylformamide (DMF) and kept at $-20^{\circ} \mathrm{C}$ in amber glass vials. The composition, 
concentration, and $\mathrm{pH}$ of the buffers employed in this study were as follows: i) PB, $100 \mathrm{mM}$ sodium phosphate buffer, $\mathrm{pH} 7.4$; ii) PBS, $10 \mathrm{mM}$ sodium phosphate buffer, $\mathrm{pH}$ 7.4, with 140 mM NaCl; iii) PBST, PBS containing 0.05\% (v/v) Tween 20; iv) PBST-FBS, PBST containing 10\% (v/v) FBS; v) PBT-FBS, 200 mM sodium phosphate buffer, $\mathrm{pH} 7.4$, containing $0.05 \%(\mathrm{v} / \mathrm{v})$ Tween 20 and 10\% (v/v) FBS; vi) CB, 50 mM carbonate-bicarbonate buffer, pH 9.6; vii) Washing solution, $150 \mathrm{mM} \mathrm{NaCl}$ and $0.05 \%$ (v/v) Tween 20; and viii) Developing buffer, 25 $\mathrm{mM}$ sodium citrate and $62 \mathrm{mM}$ sodium phosphate buffer, $\mathrm{pH} 5.4$.

\section{Hapten synthesis}

The synthesis of hapten PCa6 (1) was described in a previous article [11] and its structure is schematized in Table 1. Haptens PCb6 (2) and PCo6 (3) were prepared from 2-chloro-6-trifluoromethyl pyridine (4) or PC, respectively, following the synthetic routes depicted in Figs. 1 and 2. A detailed description of each synthetic step as well as the complete spectroscopic characterization data of haptens PCb6 and PCo6 are reported below. For spectroscopic data of all synthetic intermediates see the Supplementary Data.

\section{Synthesis of hapten PCb6 (2)}

\section{Synthesis of 2-chloro-4-iodo-6-(trifluoromethyl)pyridine (5). A solution of} 2-chloro-6-(trifluoromethyl)pyridine (4) $(1.533 \mathrm{~g}, 8.44 \mathrm{mmol})$ in $2 \mathrm{~mL}$ tetrahydrofuran (THF) was added drop wise to a solution of lithium diisopropylamide (LDA) [prepared from $1.6 \mathrm{M}$ butyllithium in hexane $(10.5 \mathrm{~mL}, 16.80 \mathrm{mmol})$ and diisopropylamine $(2.36 \mathrm{~mL}, 1.704 \mathrm{~g}, 16.84$ $\mathrm{mmol})$ in THF $(13 \mathrm{~mL})]$ at $-100{ }^{\circ} \mathrm{C}$. After $2 \mathrm{~h}$ at this temperature, a solution of $\mathrm{I}_{2}(2.14 \mathrm{~g}, 8.43$ $\mathrm{mmol}$ ) in THF ( $2 \mathrm{~mL}$ ) was slowly added (30 $\mathrm{min})$ to the orange reaction mixture, and then the mixture was allowed to warm to $-80{ }^{\circ} \mathrm{C}$ for $1 \mathrm{~h}$, poured into water, and extracted with 
$\mathrm{CH}_{2} \mathrm{Cl}_{2}$. The combined organic layers were washed with brine, dried over anhydrous $\mathrm{Na}_{2} \mathrm{SO}_{4}$, and concentrated to leave a residue that was purified by chromatography, using hexaneEtOAc (9:1) as eluent, to give iodo-pyridine 5 (1.768 g, 70\%) as a colorless solid [mp 94-94.5 ${ }^{\circ} \mathrm{C}$ (crystallized from hexane)], which had physical and spectroscopic properties identical to those reported in the literature [16].

Synthesis of 4-iodo-6-(trifluoromethyl)pyridin-2-ol (6). A mixture of chloro-pyridine 5 (802 $\mathrm{mg}, 2.6 \mathrm{mmol})$ and $\mathrm{KOH}(357 \mathrm{mg}, 6.37 \mathrm{mmol})$ in tert-butanol $(2.2 \mathrm{~mL})$ was stirred at reflux under nitrogen for $2 \mathrm{~h}$. The mixture was diluted with water, acidified with $1 \mathrm{M}$ aqueous $\mathrm{HCl}$, and extracted with EtOAc. Washing of the extracts with brine was followed by drying over anhydrous $\mathrm{Na}_{2} \mathrm{SO}_{4}$ and removal of the solvent. Chromatographic purification using mixtures of hexane and EtOAc (from 9:1 to 7:3) as eluent, afforded the 2-pyridinol 6 (621 mg, 63\%) as a white solid. Mp $147-148{ }^{\circ} \mathrm{C}$ (crystallized from hexane).

Synthesis of 2-(2-bromobenzyloxy)-4-iodo-6-(trifluoromethyl)pyridine (8). A mixture of pyridinol 6 (758 mg, $2.62 \mathrm{mg}$ ) and anhydrous $\mathrm{K}_{2} \mathrm{CO}_{3}(579 \mathrm{mg}, 4.19 \mathrm{mmol})$ in dry DMF (3 mL) was stirred at $80{ }^{\circ} \mathrm{C}$ under nitrogen for $5 \mathrm{~min}$, and then a solution of dibromide 7 (681 $\mathrm{mg}$, $2.72 \mathrm{mmol}$ ) in DMF ( $3 \mathrm{~mL}$ ) was added drop wise by a syringe pump during $4 \mathrm{~h}$. After this time, the reaction mixture was cooled down to $\mathrm{rt}$, poured into water, and extracted with EtOAc. The organic phase was washed with brine, dried over $\mathrm{Na}_{2} \mathrm{SO}_{4}$, and the residue left after evaporation of the solvent was purified by chromatography, using hexane-EtOAc (95:5), to yield the benzyl ether $8\left(930 \mathrm{mg}, 78 \%\right.$ ) as a solid. Mp $67-68{ }^{\circ} \mathrm{C}$ (crystallized from hexane).

Synthesis of tert-butyl 6-(2-(2-bromobenzyloxy)-6-(trifluoromethyl)pyridin-4-yl)hex-5ynoate (10). $\mathrm{Et}_{3} \mathrm{~N}(2.8 \mathrm{~mL}$ ) was added drop wise to a mixture of iodo pyridine 8 (480 mg, $2.139 \mathrm{mmol}$ ), tert-butyl hex-5-ynoate (9) $(378 \mathrm{mg}, 2.351 \mathrm{mmol}), \mathrm{Cl}_{2} \mathrm{Pd}\left(\mathrm{PPh}_{3}\right)_{2}$ (36.6 mg, 
$0,052 \mathrm{mmol})$, and Cul $(7.6 \mathrm{mg}, 0.040 \mathrm{mmol})$ in anhydrous DMF $(2.8 \mathrm{~mL})$ under nitrogen. The mixture was stirred at $\mathrm{rt}$ for $5 \mathrm{~h}$, poured into water $(100 \mathrm{~mL})$, and extracted with EtOAc. The combined organic extracts were washed successively with water, $2 \%$ aqueous solution of $\mathrm{LiCl}$, and brine, dried over anhydrous $\mathrm{Na}_{2} \mathrm{SO}_{4}$ and concentrated. Purification by chromatography, using hexane-EtOAc (9:1) as eluent, afforded alkyne 10 (916 mg, 86\%) as a colorless oil.

Synthesis of tert-butyl 6-(2-(2-bromobenzyloxy)-6-(trifluoromethyl)pyridin-4-yl)hexanoate (11). A solution of alkyne $10 \quad(882 \quad \mathrm{mg}, 1.783 \quad \mathrm{mmol})$ and chlorotris(triphenylphosphine)rhodium(I) $(100 \mathrm{mg}, 0.108 \mathrm{mmol}, 6 \%)$ in anhydrous THF (10.5 $\mathrm{mL}$ ) was evacuated and purged under an atmosphere of hydrogen gas. The hydrogen pressure was regulated to 4 bars and the reaction mixture was stirred at $\mathrm{rt}$ for $21 \mathrm{~h}$. Then, the solvent was removed under vacuum and the obtained residue was purified by chromatography, using hexane-EtOAc (9:1) as eluent, to give compound $\mathbf{1 1}$ (1.049 g, 92\%) as a colorless oil.

Synthesis of tert-butyl 6-(2-(2-(4,4,5,5-tetramethyl-1,3,2-dioxaborolan-2-yl)benzyloxy)-6(trifluoromethyl)pyridin-4-yl)hexanoate (12). $\mathrm{Et}_{3} \mathrm{~N}(843 \mu \mathrm{L}, 0.037 \mathrm{mmol}$ ) was added to a mixture of aryl bromide 11 (760 mg, $1.513 \mathrm{mmol}), \mathrm{Pd}(\mathrm{OAc})_{2}(8.5 \mathrm{mg}, 0.037 \mathrm{mmol})$, and 2-dicyclohexylphosphinobiphenyl (53 $\mathrm{mg}, 0.151 \mathrm{mmol}$ ) in dry dioxane $(3.6 \mathrm{~mL}$ ) under nitrogen. After stirring at $r$ for a few minutes, pinacolborane $(548 \mu \mathrm{L}, 3.782 \mathrm{mmol})$ was added and the mixture was stirred at $80{ }^{\circ} \mathrm{C}$ for $3.5 \mathrm{~h}$. The reaction mixture was cooled to $\mathrm{rt}$ and quenched by the addition of an aqueous saturated solution of $\mathrm{NH}_{4} \mathrm{Cl}$, then diluted with water, and extracted with EtOAc. The combined organic extracts were washed with brine, dried over $\mathrm{Na}_{2} \mathrm{SO}_{4}$, and concentrated. The obtained residue was purified by 
chromatography, using hexane-EtOAc (95:5) as eluent, to yield the boronic acid ester 12 (493 mg, 60\%) as an oil.

Synthesis of (E)-tert-butyl 6-(2-(2-(1,3-dimethoxy-3-oxoprop-1-en-2-yl)benzyloxy)-6(trifluoromethyl)pyridin-4-yl)hexanoate (14). A mixture of arylboronic acid 12 (472 mg, 0.861 mmol), iodoacrylate 13 (312 mg, $1.291 \mathrm{mmol}), \mathrm{K}_{3} \mathrm{PO}_{4}(548 \mathrm{mg}, 2.583 \mathrm{mmol})$, and $\mathrm{Pd}\left(\mathrm{PPh}_{3}\right)_{4}$ (39.8 $\mathrm{mg}, 0.034 \mathrm{mmol})$ in a mixture of dioxane $(3.6 \mathrm{~mL})$ and water $(0.7 \mathrm{~mL})$, previously degasified by bubbling nitrogen under ultrasonic irradiation for $10 \mathrm{~min}$, was stirred under nitrogen at $95^{\circ} \mathrm{C}$ for $10 \mathrm{~h}$ and then at $100{ }^{\circ} \mathrm{C}$ for an additional $2 \mathrm{~h}$. The reaction mixture was cooled down to rt, diluted with ethyl ether, washed with brine, and dried over anhydrous $\mathrm{Na}_{2} \mathrm{SO}_{4}$. Evaporation of the solvent and chromatographic purification of the residue, using hexane-EtOAc (9:1) as eluent, gave the methoxyacrylate derivative 14 (296 mg, 64\%) as an oil.

Synthesis of (E)-6-(2-(2-(1,3-dimethoxy-3-oxoprop-1-en-2-yl)benzyloxy)-6-(trifluoromethyl) pyridin-4-yl)hexanoic acid (hapten PCb6, 2). A solution of the tert-butyl ester 14 (101 mg, $0.188 \mathrm{mmol})$ in formic acid $(3.5 \mathrm{~mL})$ was stirred for $2 \mathrm{~h}$ at $\mathrm{rt}$ under nitrogen. The reaction mixture was diluted with benzene and washed four times with cool water and once with brine, dried over anhydrous $\mathrm{Na}_{2} \mathrm{SO}_{4}$, and concentrated under vacuum to give the crude product that was purified by chromatography, using $\mathrm{CHCl}_{3}$ as eluent, to give hapten PCb6 (2) (67 mg, 75\%) as a viscous oil. ${ }^{1} \mathrm{H}$ NMR $\left(\mathrm{C}_{6} \mathrm{D}_{6}\right), \delta: 7.59(1 \mathrm{H}, \mathrm{m}, \mathrm{H}-6 \mathrm{Ph}), 7.41(1 \mathrm{H}, \mathrm{s},=\mathrm{CH}), 7.29$ (1H, m, H-3 Ph), 7.17-7.10 (2H, m, H-4 Ph and H-5 Ph), 6.83 (1H, br s, H-5 Py), $6.48(1 \mathrm{H}, \mathrm{br}$ s, H-3 Py), $5.60\left(1 \mathrm{H}, \mathrm{s}, \mathrm{CH}_{2} \mathrm{O}\right), 3.44\left(3 \mathrm{H}, \mathrm{s}, \mathrm{CO}_{2} \mathrm{Me}\right), 2.91(2 \mathrm{H}, \mathrm{s}, \mathrm{OMe}), 2.01(2 \mathrm{H}, \mathrm{t}, J=7.3 \mathrm{~Hz}, \mathrm{H}-$ 6), $1.96(2 \mathrm{H}, \mathrm{t}, J=7.8 \mathrm{~Hz}, \mathrm{H}-2), 1.34(4 \mathrm{H}$, quint, $J=7.3 \mathrm{~Hz}, \mathrm{H}-5), 1.06(3 \mathrm{H}, \mathrm{m}, \mathrm{H}-3), 0.91(2 \mathrm{H}$, $\mathrm{m}, \mathrm{H}-4) ;{ }^{13} \mathrm{C} \operatorname{NMR}\left(\mathrm{C}_{6} \mathrm{D}_{6}\right), \delta: 179.87(\mathrm{C}-1), 167.88\left(\mathrm{CO}_{2} \mathrm{H}\right), 164.62(\mathrm{C}-2 \mathrm{Py}), 160.10(\mathrm{C}=\mathrm{CH})$, 155.71 (C-4 Py), 145.46 (q, J = 34 Hz, C-6 Py), 136.41 (C-1 Ph), 133.18(C-2 Ph), 131.69 (C-3 
Ph), 128.97 (C-6 Ph), 127.92 and 127.87 (C-4 Ph and C-5 Ph), 122.52 (q, J = $274 \mathrm{~Hz}, \mathrm{CF}_{3}$ ), 114.36 (q, $J=3 \mathrm{~Hz}, \mathrm{C}-5 \mathrm{Py}), 114.09$ (C-3 Py), 110.79 (C=CH), $66.93\left(\mathrm{CH}_{2} \mathrm{O}\right), 60.91$ (OMe), $51.22\left(\mathrm{CO}_{2} \mathrm{Me}\right.$ ), 34.66 (C-2), 33.80 (C-6), 29.43 (C-3), 28.45 (C-4), 24.41 (C-5); IR (NaCl), $v_{\max }$ : $3500-2500,3060,3033,2946,1708,1622,1567,1437,1400,1350,1259,1187,1137,1039$, 771, $733 \mathrm{~cm}^{-1}$; MS (EI), m/z (\%): $481\left(\mathrm{M}^{+}, 7\right), 450$ (4), 449 (17), 205 (21), 204 (31), 191 (8), 190 (66), 189 (14), 175 (16), 173 (18), 145 (100); HRMS: calculated for $\mathrm{C}_{24} \mathrm{H}_{26} \mathrm{~F}_{3} \mathrm{NO}_{6}$ 481.17122, found 481.17171. UV (PB), $\varepsilon\left(\mathrm{mM}^{-1} \mathrm{~cm}^{-1}\right):(280 \mathrm{~nm}) 2.81,(260 \mathrm{~nm})$ 8.37.

Synthesis of hapten PCo6 (3)

Synthesis of (E)-methyl 3-hydroxy-2-(2-((6-(trifluoromethyl)pyridin-2-yloxy)methyl) phenyl)acrylate (15). PC (518 mg, $1.410 \mathrm{mmol}$ ) was added in small portions to a well stirred solution of $\mathrm{LiOH} \cdot \mathrm{H}_{2} \mathrm{O}\left(593 \mathrm{mg}, 14.10 \mathrm{mmol}\right.$ ) and $\mathrm{Bu}_{4} \mathrm{NHSO}_{4}(479 \mathrm{mg}, 1.410 \mathrm{mmol}$ ) in a 3:1 mixture of $\mathrm{THF}-\mathrm{H}_{2} \mathrm{O}(14 \mathrm{~mL})$. The mixture was stirred at $\mathrm{rt}$ for $16 \mathrm{~h}$, then diluted with $\mathrm{H}_{2} \mathrm{O}$ (50 mL), acidified to $\mathrm{pH} \mathrm{3-4} \mathrm{with} \mathrm{solid} \mathrm{KHSO}_{4}$ and extracted with ethyl ether. The combined organic extracts were washed with brine, dried over anhydrous $\mathrm{Na}_{2} \mathrm{SO}_{4}$, and concentrated to dryness. The residue was purified by silica gel chromatography, using hexane-EtOAc (9:1) as eluent, to give enol 15 (408 mg, 82\%) as an oil [17].

Synthesis of (E)-tert-butyl 6-(3-methoxy-3-oxo-2-(2-((6-(trifluoromethyl)pyridin-2yloxy)methyl)phenyl)prop-1-enyloxy)hexanoate (17). A mixture of enol 15 (390 mg, 1.104 mol) and anhydrous $\mathrm{Cs}_{2} \mathrm{CO}_{3}(443 \mathrm{mg}, 1.359 \mathrm{mmol})$ in dry DMF $(10 \mathrm{~mL})$ was stirred at $\mathrm{rt}$ for $15 \mathrm{~min}$. tert-Butyl 6-bromohexanoate $(16,554 \mathrm{mg}, 2.208 \mathrm{mmol})$ was added and the mixture was stirred for $2 \mathrm{~h}$, then diluted with $\mathrm{H}_{2} \mathrm{O}(50 \mathrm{~mL})$, and extracted with EtOAc. The combined organic extracts were successively washed with $2 \%$ aqueous solution of $\mathrm{LiCl}$ and brine, dried 
over anhydrous $\mathrm{MgSO}_{4}$, and concentrated. The residue was chromatographed on silica gel, using hexane-EtOAc (9:1) as eluent, to give the enol ether 17 (474 mg, 82\%) as an oil.

Synthesis of (E)-6-(3-methoxy-3-oxo-2-(2-((6-(trifluoromethyl)pyridin-2-yloxy)methyl) phenyl)prop-1-enyloxy)hexanoic acid (hapten PCo6, 3). A solution of tert-butyl ester 17 (312 $\mathrm{mg}, 0.597 \mathrm{mmol})$ in dry $\mathrm{CH}_{2} \mathrm{Cl}_{2}(1 \mathrm{~mL})$ was treated with $\mathrm{CF}_{3} \mathrm{CO}_{2} \mathrm{H}(1 \mathrm{~mL})$ under nitrogen at $0{ }^{\circ} \mathrm{C}$. The mixture was stirred at the same temperature for $2 \mathrm{~h}$, then diluted with benzene, washed with brine, dried over anhydrous $\mathrm{Na}_{2} \mathrm{SO}_{4}$, and concentrated to dryness in vacuum. The residue was purified by chromatography, using $\mathrm{CHCl}_{3}-\mathrm{MeOH}(99: 1)$ as eluent, to give hapten PCo6 (270 mg, 82\%) as a viscous oil. ${ }^{1} \mathrm{H}$ NMR $\left(\mathrm{CDCl}_{3}\right), \delta: 7.68(1 \mathrm{H}, \mathrm{dd}, \mathrm{J}=8$ and $8 \mathrm{~Hz}$, H-4 Py), $7.62(1 \mathrm{H}, \mathrm{s},=\mathrm{CH}), 7.56(1 \mathrm{H}, \mathrm{m}, \mathrm{H}-3 \mathrm{Ph}), 7.33$ (2H, m, H-4 Ph and H-5 Ph), $7.23(1 \mathrm{H}, \mathrm{br}$ d, J = $8 \mathrm{~Hz}, \mathrm{H}-5 \mathrm{Py}), 7.16(1 \mathrm{H}, \mathrm{m}, \mathrm{H}-6 \mathrm{Ph}), 6.89(1 \mathrm{H}, \mathrm{br} \mathrm{d}, J=8 \mathrm{~Hz}, \mathrm{H}-3 \mathrm{Py}), 5.31\left(2 \mathrm{H}, \mathrm{s}, \mathrm{CH}_{2} \mathrm{O}\right)$, $4.00(2 \mathrm{H}, \mathrm{t}, J=7 \mathrm{~Hz}, \mathrm{H}-6), 3.67\left(3 \mathrm{H}, \mathrm{s}, \mathrm{CO}_{2} \mathrm{Me}\right), 2.93(2 \mathrm{H}, \mathrm{t}, J=7 \mathrm{~Hz}, \mathrm{H}-2), 1.69-1.49(4 \mathrm{H}, \mathrm{m}$, $\mathrm{H}-3$ and $\mathrm{H}-5), 1.33(2 \mathrm{H}, \mathrm{m}, \mathrm{H}-4) ;{ }^{13} \mathrm{C} N M R\left(\mathrm{CDCl}_{3}\right), \delta: 179.22(\mathrm{C}-1), 168.22\left(\mathrm{CO}_{2} \mathrm{Me}\right), 163.57$ (C-2 Py), $158.97(\mathrm{C}=\mathrm{CH}), 145.25$ (q, J = $34 \mathrm{~Hz}, \mathrm{C}-6 \mathrm{Py}), 139.30$ (C-4 Py), 135.50 (C-2 Ph), 132.21 (C-1 Ph), 131.03 (C-6 Ph), 128.63 (C-3 Ph), 127.71 (C-4 Ph and C-5 Ph), 121.33 (q, J = $\left.274 \mathrm{~Hz}, \mathrm{CF}_{3}\right), 114.62$ (C-3 Py), 113.21 (q, J = $\left.3 \mathrm{~Hz}, \mathrm{C}-5 \mathrm{Py}\right), 109.74(\mathrm{C}=\mathrm{CH}), 74.86$ (C-6), 66.31 $\left(\mathrm{CH}_{2} \mathrm{O}\right), 51.56\left(\mathrm{CO}_{2} \mathrm{Me}\right), 33.66$ (C-2), 29.23 (C-5), 24.85 (C-4), 24.03 (C-3); IR ( $\left.\mathrm{NaCl}\right), v_{\max }$ : $3100,2951,1708,1627,1458,1350,1285,1143,989,811,752 \mathrm{~cm}^{-1} ; \mathrm{MS}(\mathrm{EI}), \mathrm{m} / \mathrm{z}(\%): 467$ (11, M+ $) 436$ (27), 435 (100), 336 (17), 335 (85), 303 (69), 190 (49), 158 (68), 131 (83), 103 (65); HRMS: calculated for $\mathrm{C}_{23} \mathrm{H}_{24} \mathrm{~F}_{3} \mathrm{NO}_{6}$ 467.15557, found 467.15498. UV (PB), $\varepsilon\left(\mathrm{mM}^{-1}\right.$ $\left.\mathrm{cm}^{-1}\right):(280 \mathrm{~nm}) 3.13,(260 \mathrm{~nm}) 9.22$. 


\section{Preparation of protein-hapten conjugates}

All conjugates used in this study were prepared by activation of the free carboxylic group of haptens PCa6 (1), PCb6 (2), and PCo6 (3) and reaction with the free amine groups of different carrier proteins: BSA for the immunizing conjugate, OVA for coating of ELISA plates in indirect assays, and HRP as enzyme tracer for the direct formats. On the one hand, immunizing conjugates were prepared by the active ester method via an alternative procedure using $N, N^{\prime}$-disuccinimidyl carbonate (DSC) as activating reagent instead of the classical carbodiimide derivatives, as previously reported [11]. On the other hand, assay conjugates were obtained by the classical mixed anhydride procedure [18]. Three OVA conjugates were prepared from each hapten using decreasing hapten-to-protein molar ratios (MRs) in the reaction mixture $(13,7.5$, or 1.3 mole of hapten was added for coupling per mole of protein). If conjugation occurred, the UV-vis spectrum of the conjugate was slightly different from that of the free protein, so the finally achieved hapten-to-protein MR could be measured spectrophotometrically by assuming that the molar absorptions of both the hapten and the protein were the same for the free and the conjugated forms. For further details see the Supplementary Data.

\section{Production of antibodies}

Animal manipulation was performed in compliance with laws of the Spanish Ministry of Agriculture, Fisheries, and Food and following European guidelines. Two female New Zealand white rabbits weighing 1-2 kg were immunized by subcutaneous injection with 0.3 mg of BSA-hapten conjugate in $1.0 \mathrm{~mL}$ of a 1:1 mixture of conjugate solution in $\mathrm{PB}$ and complete Freund's adjuvant. Animals were boosted at 21-day intervals with the same immunogen suspended in a mixture of $0.5 \mathrm{~mL}$ of $\mathrm{PB}$ and $0.5 \mathrm{~mL}$ of incomplete Freund's 
adjuvant. Whole blood was collected from the ear vein of the rabbits and by intracardiac puncture 10 days after the fourth injection. Blood samples were allowed to coagulate overnight at $4{ }^{\circ} \mathrm{C}$. Then, the serum was separated by centrifugation and the immunoglobulin fraction was precipitated by adding 1 volume of a saturated ammonium sulfate solution. After centrifugation at $4000 \times \mathrm{g}$ for $0.5 \mathrm{~h}$, the pellet was resuspended in 1 volume of PBS and a fraction was diluted $1 / 5$ with PBS containing $0.01 \%$ thimerosal $(w / v)$ and kept at $4{ }^{\circ} \mathrm{C}$ for daily usage. The remainder of each antiserum was precipitated again as before and stored at $4{ }^{\circ} \mathrm{C}$.

Direct cELISA procedures

Direct assays were performed with and without a capture antibody. Ninety-six-well polystyrene ELISA plates were coated with $100 \mu \mathrm{L}$ per well of antibody dilution in CB by overnight incubation at rt. In between steps, plates were washed four times with washing solution. For capture-antibody assays, a coating GAR solution was used, and after washing $100 \mu \mathrm{L}$ of anti-PC pAb solution was added per well, then plates were incubated $1 \mathrm{~h}$ at $\mathrm{rt}$ and washed as before. In both formats, the competitive step was carried out with $50 \mu \mathrm{L}$ per well of analyte standard solution in PBS plus $50 \mu \mathrm{L}$ per well of HRP tracer dilution in PBST. The immunological reaction took place during $1 \mathrm{~h}$ at $\mathrm{rt}$, and plates were washed again as described. Finally, signal was generated by addition of $100 \mu \mathrm{L}$ per well of freshly prepared $2 \mathrm{mg} / \mathrm{mL}$ o-phenylendiamine and $0.012 \%(\mathrm{v} / \mathrm{v}) \mathrm{H}_{2} \mathrm{O}_{2}$ in developing buffer. After $10 \mathrm{~min}$ at $\mathrm{rt}$, the enzymatic reaction was stopped by addition of $100 \mu \mathrm{L}$ per well of $2.5 \mathrm{M}$ sulfuric acid. The absorbance was immediately read at $492 \mathrm{~nm}$ using a reference wavelength of $650 \mathrm{~nm}$. 
Indirect CELISA procedure

Microplates were coated with $100 \mu \mathrm{L}$ per well of OVA-hapten solution in CB by overnight incubation at rt. Coated plates were washed four times with washing solution and then received $50 \mu \mathrm{L}$ per well of analyte standard solution in PBS plus $50 \mu \mathrm{L}$ per well of anti-PC $\mathrm{pAb}$ in PBST-FBS. The immunological reaction took place during $1 \mathrm{~h}$ at $\mathrm{rt}$, and plates were washed again as described above. Next, $100 \mu \mathrm{L}$ per well of a $1 / 10^{4}$ dilution of GAR-HRP conjugate in PBST-FBS was added, and then plates were incubated $1 \mathrm{~h}$ at $\mathrm{rt}$ and washed as before. Finally, the signal was produced as aforementioned.

\section{Buffer studies}

The influence of the ionic strength and $\mathrm{pH}$ over the inhibition curve parameters was studied using a series of buffers prepared as follows. First, a $40 \mathrm{mM}$ trisodium citrate, 40 $\mathrm{mM}$ disodium hydrogenphosphate and $40 \mathrm{mM}$ Tris solution ( $\mathrm{pH} 9.9)$ was prepared and known volumes of $5 \mathrm{M} \mathrm{HCl}$ was added in order to reach the required $\mathrm{pH}$ in each case. Then, the ionic strength of all buffers was fixed by adding the appropriate volume of a $2 \mathrm{M} \mathrm{NaCl}$ solution and taking into account the initial solution and the added $\mathrm{HCl}$. Finally, Tween 20 was added before the final volume was achieved with deionized water. PC standard curves were prepared in water, and they were mixed with the tracer dilution for direct competitive assays or with the polyclonal solution for indirect competitive assays in every of the prepared buffers. Changes in the PC inhibition curve parameters using distinct buffers were fitted by a multiple regression equation, including curvature and interaction terms, using Minitab 14.1 software (Minitab Inc., State College, PA, USA) as previously published [19]. 


\section{Analyte extraction}

Soybean sprouts were purchased from local markets and short-term stored at $4{ }^{\circ} \mathrm{C}$. Samples were chopped and homogenized using a T-25 ultra-turrax blender from IKA (Staufen, Germany) and if required stored at $-20^{\circ} \mathrm{C}$. Extraction of PC from soybean samples was performed by the QuEChERS method [20] using the DisQuE dispersive sample preparation kit from Waters (Milford, MA, USA) without dispersive solid phase extraction. Briefly, $15 \mathrm{~g}$ of homogenate was introduced in a $50 \mathrm{~mL}$ polypropylene centrifuge tube with $1.5 \mathrm{~g}$ of NaOAc, $6 \mathrm{~g}$ of $\mathrm{MgSO}_{4}$, and $15 \mathrm{~mL}$ of $1 \% \mathrm{HOAc}$ in acetonitrile. Tubes were vigorously shaken using a vortex mixer and then centrifuged at $2200 \times \mathrm{g}$ for $5 \mathrm{~min}$. The organic extracts were analyzed by the optimized indirect cELISA after being properly diluted with deionized water.

\section{Data treatment}

Calibration standards were prepared by 6-fold serial dilution from a $1 \mathrm{mM}$ PC stock solution in DMF. Experimental values were fitted to a four-parameter logistic equation using the SigmaPlot software package from SPSS Inc. (Chicago, IL, USA). Assay detectability was estimated as the concentration of analyte at the inflection point of the sigmoidal curve, typically corresponding to a $50 \%$ inhibition $\left(\mathrm{IC}_{50}\right)$ of the maximum absorbance reached at the zero dose of analyte $\left(A_{\max }\right)$ if the background signal approaches to zero. The limit of detection (LOD) was estimated as the concentration of PC that provided a $10 \%$ inhibition of $A_{\max }$, whereas the analytical working range was calculated as the PC concentration that provided from 20 to $90 \%$ inhibition of $A_{\max }$. 


\section{Results and discussion}

Haptens synthesis and conjugate preparation

In this study, three haptens, namely PCa6 (1), PCb6 (2), and PCo6 (3) (Table 1), were used for antibody generation and immunoassay development. The strategy for the preparation of PCb6 (2) was based on that previously reported for hapten PCa6 (1) [11] and for some functionalized derivatives of the related strobilurin fungicide azoxystrobin [21]. Such approach relies on the different reactivity of aryl iodide and bromide groups towards palladium-catalyzed Sonogashira and Suzuki-Miyaura cross-coupling reactions, as key steps for the modular incorporation of the hydrocarbon spacer chain and the 6 -methoxyacrylate moiety, respectively. The designed synthetic scheme for hapten PCb6, summarized in Fig. 1, required the initial preparation of a fragment containing the pyridine and phenyl moieties (intermediate 8), which was synthesized starting with iodination of the C-4 position of 2chloro-6-trifluoromethy pyridine (4) and, following the Schlosser protocol [16], it was transformed into 4-iodo pyridine 5. Replacement of the chlorine atom by a hydroxyl group, followed by 0 -alkylation of the thus-formed 2-pyridinol 6 with 1-bromo-2-(bromomethyl)benzene (7) catalyzed by $\mathrm{K}_{2} \mathrm{CO}_{3}$ led to the required benzyl ether 8. This compound underwent a chemoselective and efficient palladium-catalyzed Sonogashira reaction with tert-butyl hex-5-ynoate (9) to give the acetylenic compound 10. Such cross-coupling reaction was very selective and no substantial reaction at the phenylbrominated position was observed. Homogeneous catalyzed hydrogenation of the triple bond of 10 using Wilkinson's catalyst afforded the C-4 alkylated pyridine derivative 11, thus completing the introduction of the C6 hydrocarbon chain that constituted the spacer arm of this hapten. Introduction of the 8 -methoxyacrylate moiety that completed the PCb6 hapten 
framework was achieved through a Suzuki-Miyaura reaction. First, the aryl bromide $\mathbf{1 1}$ was converted to the arylboronic ester $\mathbf{1 2}$ by treatment with pinacolborane and $\mathrm{Pd}(\mathrm{OAc})_{2} / 2$-(dicyclohexylphosphino)biphenyl in $\mathrm{Et}_{3} \mathrm{~N}$-dioxane, which was then subjected to a second Pd-catalyzed cross-coupling reaction with methyl (Z)-2-iodo-3-methoxyacrylate (13) to yield the 6 -aryl- 6 -methoxyacrylate 14 in a moderate $40 \%$ overall yield from the starting aryl bromide 11. Finally, chemoselective formic acid-promoted hydrolysis of the tert-butyl ester moiety of $\mathbf{1 4}$ afforded hapten PCb6 (2) in good yield.

Hapten PCo6 (3) was readily prepared from commercial PC through a three-step procedure (Fig. 2). First, the B-methoxyacrylate moiety of PC was hydrolyzed to the corresponding enol (15) by treatment with $\mathrm{LiOH}$ and $\mathrm{Bu}_{4} \mathrm{NHSO}_{4}$ in a mixture of THF-water. Despite the strong basic medium that was employed, the reaction took place quite cleanly under these conditions, probably through Michael addition of the hydroxyl anion followed by elimination of the methoxyl group, with only a small amount (ca. 10\%) of the carboxylic acid being formed by hydrolysis of the methyl ester moiety. Next, the spacer group was covalently bound to the hydroxyl moiety of $\mathbf{1 5}$ via O-alkylation reaction with tert-butyl 6-bromohexanoate (16) and $\mathrm{Cs}_{2} \mathrm{CO}_{3}$ as basic catalyst in DMF to give the enol ether 17, whose tert-butyl ester moiety was chemoselectively hydrolyzed to the corresponding acid by treatment with formic acid at rt. Hapten PCo6 (3) was thus obtained in about 55\% overall yield from starting PC.

The three haptens (PCa6, PCb6, and PCo6) incorporated the same spacer arm, a six carbon-atom linker consisting of a linear aliphatic saturated chain, attached to three rationally-selected tethering sites of the $\mathrm{PC}$ molecule. In hapten $\mathrm{PCa6}$, the linker was anchored to the central aryl bridge that is present in all synthetic strobilurins; in hapten PCb6, the derivatization site was located at the characteristic moiety of PC; and in PCo6, the 
arm was introduced at the 6 -methoxyacrylate pharmacophore group. A three dimensional representation of one of the energetically-equivalent most stable conformations of PC showed that the three selected derivatization sites allowed the target molecule to be displayed from scattered angles (Fig. 3). Moreover, these synthetic haptens preserved the entire skeleton and functional groups of $\mathrm{PC}$, and in all cases a $\mathrm{C}-\mathrm{C}$ covalent bond replacing a $\mathrm{C}-\mathrm{H}$ chemical bond was formed between the molecule and the spacer. Therefore, no or minor modifications of steric and electronic features of the target compound were expected.

Immunizing conjugates were prepared by the active ester method from the purified $\mathrm{N}$ succinimidyl ester of the hapten. Activation of the carboxyl moiety was easily achieved with high yields (80\%) using DSC as described in the Supplementary Data. Purification of the active ester could be accomplished without difficulty by chromatography on silica gel because no significant by-products were formed during the activation reaction. After coupling, the conjugate was purified by gel filtration and the calculated hapten-to-protein MRs of the BSA conjugates were 16, 13, and 20 for PCa6, PCb6, and PCo6 conjugates, respectively. On the other hand, assay conjugates were prepared by the classical mixed anhydride method. Three OVA conjugates were prepared with different amounts of each hapten, and the calculated final MRs were 6, 3, and 1, for the OVA-PCa6 conjugates, 5, 3, and 1 for the OVA-PCb6 conjugates, and 4, 2, and 1 for the OVA-PCo6 conjugates.

\section{Assay format and immunoreagent selection}

Two pAbs were obtained with every immunizing hapten; namely, antisera rPCa6\#1 and rPCa6\#2 were produced from hapten PCa6, antisera rPCb6\#1 and rPCb6\#2 from PCb6, and antisera rPCo6\#1 and rPCo6\#2 from the PCo6-based immunogen. Combinations of all 
antisera and all conjugates were evaluated using the direct and indirect cELISA formats. Checkerboard direct competitive assays were performed by coating with antiserum dilutions (from $1 / 1000$ to $1 / 30000$ ) in $C B$, and mixing tracer solutions (from 30 to $1000 \mathrm{ng} / \mathrm{mL}$ ) in PBST with a complete PC standard curve in PBS. Very low absorbance signals were obtained under these conditions (results not shown), suggesting either a low recognition of tracer conjugates or a loss of antibody activity due to the coating process. Antibody inactivation due to direct immobilization on polystyrene plates can often be avoided by pre-coating the microwells with a capture bioreceptor $[22,23]$. Accordingly, antisera were evaluated in the direct CELISA format in wells pre-coated with an anti-rabbit immunoglobulin antibody. In this so-called capture-antibody cELISA format, GAR-coated plates received different dilutions of anti-PC antiserum in PBST, and checkerboard competitive assays were performed as aforementioned. With this procedure, antisera binding properties partially increased, although in order to obtain adequate maximum signals the required concentration of immunoreagents (antisera and/or enzyme tracers) were mostly unusually high (Table 2). All three immunogens generated high-affinity antibodies, with $\mathrm{IC}_{50}$ values in the low part-per-billion range. However, assays with $\mathrm{IC}_{50}$ values below $1 \mathrm{ng} / \mathrm{mL}$ were only reached with antisera derived from the PCo6-based immunogen, due perhaps to the higher degrees of freedom of the 6 -methoxyacrylate moiety. It was also observed that antibodies obtained with BSA-PCb6 only recognized the homologous antigen; likewise, the tracer HRPPCb6 was only bound by PCb6-type antibodies. However, antibodies derived from PCa6 could generally bind the tracer of PCo6, and vice versa; that is, PCo6-type antibodies also recognized HRP-PCa6. It seems that $\mathrm{PCa} 6$ - and PCo6-based immunogens generated antibodies with a binding pocket in which the pyridyl ring of the PC molecule played a determinant role, whereas antisera obtained by immunization with BSA-PCb6 did not 
accept antigens with the tethering site at the aryl ring ( $\mathrm{PCa} 6)$ or at the pharmacophore group (PCo6). Similar results have also been found with antisera generated against siteheterologous immunogens of azoxystrobin (unpublished results) and pyraclostrobin [24].

Checkerboard competitive titration assays were carried out as well in the conjugatecoated indirect ELISA format. Plates were coated with OVA-PCa6 (MR =6), OVA-PCb6 (MR = 5), and OVA-PCo6 $(M R=4)$ at two concentrations (100 and $1000 \mathrm{ng} / \mathrm{mL}$ ) in $\mathrm{CB}$, and the immunological reaction was performed with four antibody dilutions (from $1 / 3000$ to 1/100000) in PBST-FBS and PC standard solutions in PBS. In this format, a set of inhibition curves could be obtained for most pairs of immunoreagents, reaching variable $A_{\max }$ values. Table 3 lists, for each antibody-antigen combination, the representative parameters of that particular inhibition curve displaying the lowest $I_{50}$ and an $A_{\max }$ above 0.8 . This cELISA format tolerated more heterologous combinations than the direct assays. Nevertheless, like in the previous format, no assay could be obtained with PCa6-type antisera combined with the coating conjugate of hapten PCb6. Regarding detectability, the IC $\mathrm{C}_{50}$ values for PCb6- and PCo6-derived pAbs were below $3.60 \mathrm{ng} / \mathrm{mL}$, whereas PCa6-based immunogens afforded antibodies with the lowest affinity to PC. However, a proper heterologous antigen, such as OVA-PCo6, could help to achieve good detectability with medium-affinity antisera, like rPCa6\#1 and rPCa6\#2. The best immunoassay was achieved with pAb rPCo6\#1 and conjugate OVA-PCa6. This result could be explained by the nearer position of the spacer arm in haptens PCo6 and PCa6 as compared with the tethering site in hapten PCb6 (Fig. 3).

Cross-reactivity studies were performed in order to find other pesticides that could be recognized by the produced pAbs. Consequently, eight strobilurin fungicides (kresoximmethyl, trifloxystrobin, pyraclostrobin, azoxystrobin, dimoxystrobin, fluoxastrobin, metominostrobin, and orysastrobin) were assayed. Calibration curves were prepared up to 
$1 \mathrm{mg} / \mathrm{L}$ in PBS and measured by homologous indirect cELISA. Higher concentrations could not be tested because of the low water solubility of the studied compounds. Under these conditions, none of the produced pAbs showed cross-reactivity values higher than $0.1 \%$. This result indicated that all three immunizing haptens, despite the different site to which the spacer arm was attached, gave rise to equally selective antibodies.

For further ELISA development, a heterologous assay was selected in the conjugatecoated indirect competitive format taking into consideration not only the achieved detectability but also immunoreagent economy. Thus, for sensitive and selective PC detection and analysis, antigen OVA-PCa6 and antiserum rPCo6\#1 were employed for microplate coating and for analyte binding, respectively.

\section{Molar ratio of the OVA-hapten conjugates}

The effect of reducing the hapten density of the OVA-PCa6 conjugate was evaluated with antibody rPCo6\#1. Checkerboard cELISAs were carried out with antigens bearing different hapten-to-protein ratios $(5,3$, and 1). Plates were coated with each OVA-PCa6 conjugate at 100,300 , and $1000 \mathrm{ng} / \mathrm{mL}$ in $\mathrm{CB}$, and then several rPCo6\#1 dilutions (from 1/1000 to 1/30000) in PBST-FBS and a PC standard curve in PBS were added. Table 4 shows the four parameters of the best inhibition curve for every evaluated coating condition. If the antigen with the lower hapten density was used, the $A_{\max }$ values were too low, and raising the antibody concentration made the $A_{\min }$ values to increase. The use of the OVA-PCa6 conjugate with an intermediate hapten density $(M R=3)$ at $1000 \mathrm{ng} / \mathrm{mL}$ together with rPCo6\#1 antibody at a 1/10000 dilution, provided more sensitive assays, with a lower antibody consumption, and slightly better background signals than with the antigen of a 
higher MR. Therefore, further studies went on with the OVA-PCa6 conjugate of moderate haptenic charge.

\section{Solvent tolerance}

Organic solvents are commonly required for pesticide extraction from solid samples. The presence of solvents in the measured sample solution may interfere with the interaction between antibody and analyte, providing an erroneous response. For that reason, changes in the key parameters of the inhibition curve $\left(A_{\max }\right.$ and $\left.I C_{50}\right)$ were monitored using $P C$ standards prepared in PBS containing different percentages of methanol, ethanol, acetonitrile, or acetone (Fig. 4). The presence of acetone or acetonitrile in the assay strongly modified the immunological reaction. On the contrary, $10 \%$ methanol had a minor effect over the standard curve, whereas ethanol showed an intermediate behavior.

\section{Buffer conditions}

The influence of buffer conditions ( $\mathrm{pH}$ and ionic strength) over the immunoassay was evaluated by a multiparametric strategy. Three buffer systems, i.e. citrate $\left(\mathrm{pKa}_{2}=4.8, \mathrm{pKa}_{3}=\right.$ 6.4), phosphate $\left(\mathrm{pKa}_{2}=7.2\right)$, and Tris $(\mathrm{pKa}=8.1)$, together with $\mathrm{NaCl}$, were employed to adjust $\mathrm{pH}$ and ionic strength values, as described by Abad-Fuentes et al. [19]. Tween 20 and FBS were added at a fixed concentration $(0.05 \%$ and $10 \%$, respectively) in order to reduce unspecific interactions. A full factorial design, including 4 square, 4 axial, and 5 centre points $(n=3)$, was employed with assay $\mathrm{pH}$ values from 5.5 to 9.5 , ionic strengths from 50 to 300 $\mathrm{mM}$, and PBST-FBS conditions as the center point (see Table S1 of the Supplementary Data). Conjugate-coated cELISAs were carried out using PC standard curves in water, whereas pAb rPCo6\#1 was diluted $(1 / 10000)$ in every evaluated buffer. $A_{\max }$ and $I C_{50}$ were taken as 
response values and fitted to a multiple regression equation, including curvature and interaction terms, using the Minitab software.

Significant changes over the inhibition curve parameters were observed upon $\mathrm{pH}$ and ionic strength variations (see the respective contour plots in Fig. S1 of the Supplementary Data). The $A_{\max }$ value was maximum at $\mathrm{pH}$ close to 7.5 and it decreased at acidic and basic pHs, whereas it decreased at higher ionic strength values. In the case of assay detectability, the lowest $\mathrm{IC}_{50}$ was reached at acidic $\mathrm{pHs}$ and high $\mathrm{NaCl}$ concentrations. When the $\mathrm{A}_{\max }$ and $\mathrm{IC}_{50}$ contour plots were overlaid (Fig. 5), a constricted area of $\mathrm{pH}$ and ionic strength variations was clearly defined in which changes in those parameters remained tolerable; that is, between 80 and $120 \%$. Consequently, in order to guarantee minimum pH variations during food analysis, a more concentrated buffer than PBS was investigated. Fig. 6 shows the sigmoidal curves obtained for the heterologous CELISA using rPCo6\#1 and OVA-PCa6 $(\mathrm{MR}=3)$ in two buffer systems with the same $\mathrm{pH}$ and equivalent ionic strength but different buffering capacity. Since both buffer systems afforded equivalent results, a more concentrated buffer (PBT-FBS) was selected for antiserum dilution in further studies using food samples. At the end of the whole optimization process, the $\mathrm{IC}_{50}$ value of the assay was $0.13 \pm 0.01 \mathrm{ng} / \mathrm{mL}$, the calculated LOD was $0.02 \mathrm{ng} / \mathrm{mL}$, and the working analytical range was established between 0.03 and $1.30 \mathrm{ng} / \mathrm{mL}$.

\section{Analysis of PC in spiked soybean sprouts}

The final aim of the present study was the development of a bioanalytical system for the determination of PC residues in food. Soybean sprouts were selected as a model oilseed foodstuff, and the well-known multiresidue QuEChERS methodology [25], based on an acetonitrile extraction of acetate-buffered samples, was employed for pesticide recovery. 
Sample preparation for ELISA analysis usually consists in a simple dilution of the extracts with assay buffer $[26,27]$. Accordingly, PC standard curves were prepared in diluted soybean sprout extracts $(1 / 10,1 / 30,1 / 100,1 / 300$, and $1 / 1000$ with deionized water) to assess the matrix effects on curve parameters (Fig. 7). An evident reduction in assay signal was observed at extract dilutions lower than 100 fold, so this factor was taken as the minimum required dilution to obtain reliable results.

Trueness and precision of PC determinations were evaluated by measuring QuEChERSbased extracts of soybean sprouts which had been fortified with PC at concentrations ranging from 5 to $1000 \mu \mathrm{g} / \mathrm{kg}$. Unspiked soybean extracts were also included as negative controls. Table 5 shows the recoveries obtained for PC-spiked samples at three dilution levels $(1 / 100,1 / 300$, and $1 / 1000)$ in order to cover the quantification range of the assay. The precision of the developed ELISA was satisfactory, with relative standard deviation values lower than $20 \%$ in all cases. Our results also showed that PC residues in soybean sprouts could be determined by this cELISA with quantitative recoveries (from 92 to $118 \%$ ). From this study, the limit of quantification (LOQ) for the optimized immunoassay could be established at $5 \mu \mathrm{g} / \mathrm{kg}$.

In this study, we observed that the derivatization of the PC molecule at the 6-methoxyacrylate moiety generated pAbs with higher affinity. Assay detectability could be improved using a site-heterologous antigen, though application of such a strategy with the direct CELISA format meant binding failure in many cases. The observed results could be explained by a differential display of the PC molecular framework in haptens PCa6, PCb6, and PCo6. A competitive immunoassay was optimized in the indirect ELISA format, and the hapten density of antigens was revealed as an important factor to be studied. Finally, the developed assay was applied to the analysis of PC in fortified soybean sprouts as a proof of 
concept. Further studies are being carried out with other oilseed samples and cereals, including samples from the market, which will be used to comprehensively validate the described immunochemical assay.

\section{Acknowledgements}

This work was supported by Ministerio de Educación y Ciencia (AGL2006-12750-C0201/02/ALI) and cofinanced by FEDER funds. J.P. was hired by Consejo Superior de Investigaciones Científicas (CSIC) under a predoctoral I3P contract of Ministerio de Ciencia e Innovación and the European Social Fund. F.A.E.T. and J.V.M. were hired by CSIC with postdoctoral contracts, the former under the Juan de la Cierva Program and the latter under the Ramón y Cajal Program, both cofinanced by Ministerio de Ciencia e Innovación and by the European Social Fund. We also thank Ana Izquierdo-Gil and Laura López-Sánchez for excellent technical assistance.

Limited amounts of the described immunoreagents are available upon request.

\section{Appendix A. Supplementary data}

Supplementary data associated with this article can be found, in the online version, at doi:10.1016/. 


\section{References}

[1] H. Holthues, U. Pfeifer-Fukumura, I. Sound, W. Baumann, Evaluation of the concept of heterology in a monoclonal antibody-based ELISA utilizing direct hapten linkage to polystyrene microtiter plates, J. Immunol. Methods 304 (2005) 68-77.

[2] W.-J. Gui, Y.-H. Liu, C.-M. Wang, X. Liang, G.-N. Zhu, Development of a direct competitive enzyme-linked immunosorbent assay for parathion residue in food samples, Anal. Biochem. 393 (2009) 88-94.

[3] T. Xu , K.Y. Wei , J. Wang, S.A. Eremin , S.Z. Liu , Q.X. Li , J. Li, Development of an enzyme-linked immunosorbent assay specific to Sudan red I, Anal. Biochem. 405 (2010) 41-49.

[4] C. Suárez-Pantaleón, J.V. Mercader, C. Agulló, A. Abad-Somovilla, A. Abad-Fuentes, Forchlorfenuron-mimicking haptens: from immunogen design to antibody characterization by hierarchical clustering analysis, Org. Biomol. Chem. (2011), DOI:10.1039/C1OB05190C.

[5] H. Sauter, W. Steiglich, T. Anke, Strobilurins: evolution of a new class of active substances, Angew. Chem. Int. Ed. 38 (1999) 1328-1349.

[6] D.W. Bartlett, J.M. Clough, J.R. Godwin, A.A. Hall, M. Hamer, B. Parr-Dobrzanski, Review. The strobilurin fungicides, Pest. Manag. Sci. 58 (2002) 649-662.

[7] European Commission, Commission Directive 2003/84/EC of 25 September 2003 amending Council Directive 91/414/EEC to include flurtamone, flufenacet, iodosulfuron, dimethenamid-p, picoxystrobin, fosthiazate and silthiofam as active substances, Official Journal of the European Union L-247 (2003) 20-25.

[8] S. Walorczyk, B. Gnusowski, Development and validation of a multi-residue method for the determination of pesticides in honeybees using acetonitrile-based extraction and 
gas chromatography-tandem quadrupole mass spectrometry, J. Chromatogr. A 1216 (2009) 6522-6531.

[9] N. Campillo, P. Viñas, N. Aguinaga, G. Férez, M. Hernández-Córdoba, Stir bar sorptive extraction coupled to liquid chromatography for the analysis of strobilurin fungicides in fruit samples, J. Chromatogr. A 1217 (2010) 4529-4534.

[10] P. Viñas, N. Martínez-Castillo, N. Campillo, M. Hernández-Córdoba, Liquid-liquid microextraction methods based on ultrasound-assisted emulsification and single-drop coupled to gas chromatography-mass spectrometry for determining strobilurin and oxazole fungicides in juices and fruits, J. Chromatogr. A 1217 (2010) 6569-6577.

[11] F.A. Esteve-Turrillas, J. Parra, A. Abad-Fuentes, C. Agulló, A. Abad-Somovilla, J.V. Mercader, Hapten synthesis, monoclonal antibody generation, and development of competitive immunoassays for the analysis of picoxystrobin in beer, Anal. Chim. Acta $682(2010)$ 1727-1733.

[12] J.V. Mercader, C. Suárez-Pantaleón, C. Agulló, A. Abad-Somovilla, A. Abad-Fuentes, Production and characterization of monoclonal antibodies specific to the strobilurin pesticide pyraclostrobin, J. Agric. Food Chem. 56 (2008) 7682-7690.

[13] Y. Zhang, K. Shibatomi, H. Yamamoto, Lewis acid catalyzed highly selective halogenation of aromatic compounds, Synlett 18 (2005) 2837-2842.

[14] G. Bartoli, M. Bosco, A. Carlone, R. Dalpozzo, E. Marcantoni, P. Melchiorre, L. Sambri, Reaction of dicarbonates with carboxylic acids catalyzed by weak Lewis acids: general method for the synthesis of anhydrides and esters, Synthesis 22 (2007) 3489-3496.

[15] D.M. Hodgson, J. Witherington, B.A. Moloney, L.C. Richards, J.L. Brayer, Pd/Cu cocatalyzed cross-coupling reactions of methyl 
(Z)-2-tributylstannyl-3-methoxypropenoate: a method for direct introduction of the agrochemically important B-methoxyacrylate toxophore, Synlett 1 (1995) 32-34.

[16] F. Mongin, A. Tognini, F. Cottet, M. Schlosser, Halogen shuffling in pyridines: site selective electrophilic substitutions of 2-chloro-6-(trifluoromethyl)pyridine, Tetrahedron Lett. 39 (1998) 1749-1752.

[17] P.A. Worthington, G.R. Munns, R.V. Jones, M.C.H. Standen, D.J. Ritchie, J. Forrester, Process for the preparation of 2-(6-substituted pyrid-2-yloxymethyl)phenylacetate, Int. Pat. WO 97/01538 (1997).

[18] K.M. Rajkowski, N. Cittanova, B. Desfosses, M.F. Jayle, The conjugation of testosterone with horseradish peroxidase and a sensitive enzyme assay for the conjúgate, Steroids 29 (1977) 701-713.

[19] A. Abad-Fuentes, F.A. Esteve-Turrillas, C. Agulló, A. Abad-Somovilla, J.V. Mercader, Development of competitive enzyme-linked immunosorbent assays for boscalid determination in fruit juices, Food Chem. Submitted.

[20] M. Anastassiades, S.J. Lehotay, D. Stajnbaher and F.J. Schenck, Fast and easy multiresidue method employing acetonitrile extraction/partitioning and "dispersive solid-phase extraction" for the determination of pesticide residues in produce, J. AOAC Int. 86 (2003) 412-431.

[21] J. Parra, J.V. Mercader, C. Agulló, A. Abad-Fuentes, A. Abad-Somovilla, Concise and modular synthesis of regioisomeric haptens for the production of high-affinity and stereoselective antibodies to the strobilurin azoxystrobin, Tetrahedron 67 (2011) 624635.

[22]Y. Jung, J.Y. Jeong, B.H. Chung, Recent advances in immobilization methods of antibodies on solid supports, Analyst 133 (2008) 697-701. 
[23] N. Tajima, M. Takai, K. Ishihara, Significance of antibody orientation unraveled: Welloriented antibodies recorded high binding affinity, Anal. Chem. 83 (2011) 1969-1976.

[24] J.V. Mercader, C. Agulló, A. Abad-Somovilla, A. Abad-Fuentes, Synthesis of siteheterologous haptens for high-affinity anti-pyraclostrobin antibody generation, Org. Biomol. Chem. 9 (2011) 1443-1453.

[25] L. Pareja, V. Cesio, H. Heinzen, A.R. Fernández-Alba, Evaluation of various QuEChERS based methods for the analysis of herbicides and other commonly used pesticides in polished rice by LC-MS/MS, Talanta 83 (2011) 1613-1622.

[26] C. Suárez-Pantaleón, J.V. Mercader, C. Agulló, A. Abad-Somovilla, A. Abad-Fuentes, Hapten synthesis and policlonal antibody-based immunoassay development for the analysis of forchlorfenuron in kiwifruit, J. Agric. Food Chem. 58 (2010) 8502-8511.

[27] F.A. Esteve-Turrillas, A. Abad-Fuentes, J.V. Mercader, Determination of fenhexamid residues in grape must, kiwifruit, and strawberry samples by enzyme-linked immunosorbent assay, Food Chem. 124 (2011) 1727-1733.

\section{Footnotes}

${ }^{1}$ Abbreviations used: ELISA, enzyme-linked immunosorbent assay; PC, picoxystrobin; pAb, polyclonal antibody; cELISA, competitive ELISA; rt, room temperature; HRMS, high resolution mass spectrometry; El, electron-impact; HRP, horseradish peroxidase; OVA, ovalbumin; GAR, goat anti-rabbit immunoglobulin; BSA, bovine serum albumin; FBS, fetal bovine serum; DMF, N,N-dimethylformamide; THF, tetrahydrofuran; LDA, lithium diisopropylamide; DSC, N,N'-disuccinimidyl carbonate; MR, molar ratio; LOD, limit of detection; LOQ, limit of quantification. For buffer name abbreviations and composition see the Materials and Methods section. 


\section{Figure legends}

Fig. 1

Synthesis of hapten PCb6.

Fig. 2

Synthesis of hapten PCo6.

Fig. 3

One of the most stable conformations of PC, calculated using CONFLEX with MM3 molecular mechanics to systematically search for low energy conformers (CAChe worksystem Pro Version 7.5.0.85). The elements are represented in the following manner: carbon, grey; oxygen, red; nitrogen, blue; fluorine, green. The arrows point out the attachment sites of the $\mathrm{C} 6$ hydrocarbon spacer arm of haptens PCa6, PCb6, and PCo6.

Fig. 4

Influence of solvent concentration over the signal $\left(A_{\max }\right)$ and detectability $\left(I C_{50}\right)$ of the competitive assay with pAb rPCo6\#1 and the heterologous coating conjugate OVA-PCa6 $(M R=3)$. Values are the mean of four independent determinations.

Fig. 5

Overlaid contour plots of the variation (\%) of $A_{\max }$ and $I C_{50}$ values with respect to buffer $\mathrm{pH}$ and ionic strength $(I)$. The white area sets the limits of acceptable $\mathrm{pH}$ and $/$ conditions.

Fig. 6

Standard inhibition curves for PC obtained by cELISA in two buffer systems with equivalent ionic strength but different phosphate concentration, $10 \mathrm{mM}$ (triangles) and $100 \mathrm{mM}$ 
(circles), using plates coated with OVA-PCa6 $(\mathrm{MR}=3)$ at $1000 \mathrm{ng} / \mathrm{mL}$ and antiserum rPCo6\#1 diluted 1/10000. Values are the mean of three independent experiments. The $A_{\max }$ values were between 0.8 and 1.2 , the slopes were about -0.9 , and the lower asymptotes were below $15 \%$ of the $A_{\max }$.

\section{Fig. 7}

Matrix interferences produced by QuEChERS-based soybean sprout extracts over the inhibition curve of the rPCo6\#1 conjugate-coated cELISA. 

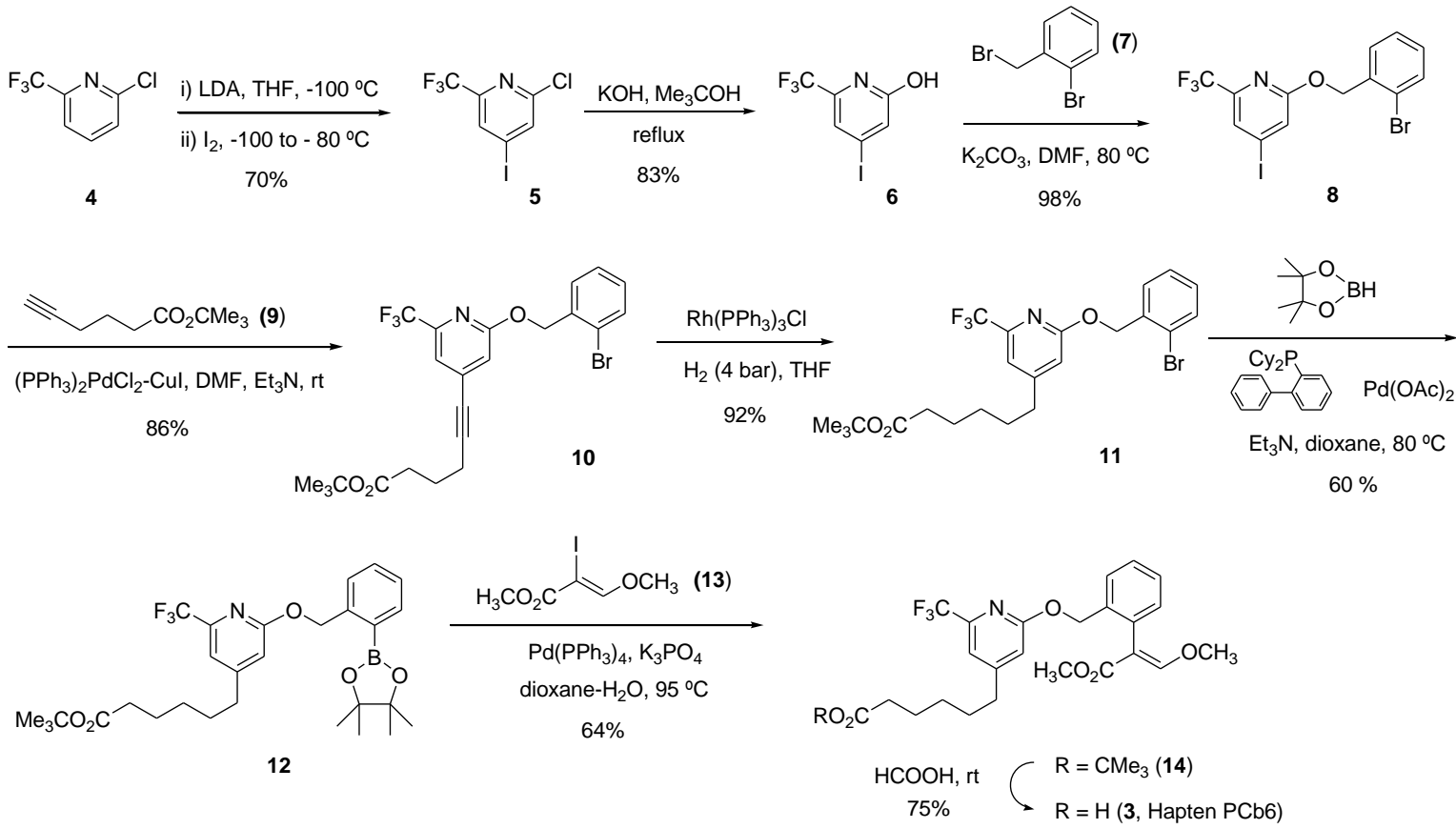

Figure 1, Parra et al. 

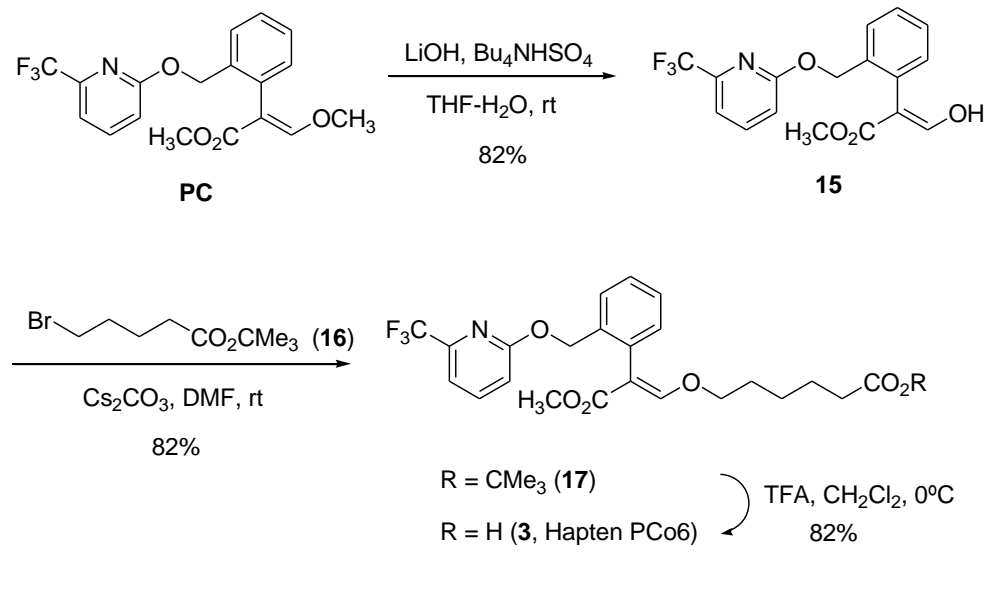

Figure 2, Parra et al.

(1)

$$
\begin{aligned}
& \mathrm{R}=\mathrm{CMe}_{3}(\mathbf{1 7}) \\
& \mathrm{R}=\mathrm{H}(\mathbf{3}, \text { Hapten PCo6) }
\end{aligned} \quad \begin{gathered}
\mathrm{TFA}, \mathrm{CH}_{2} \mathrm{Cl}_{2}, 0^{\circ} \mathrm{C} \\
82 \%
\end{gathered}
$$

$x^{2}$

(1)

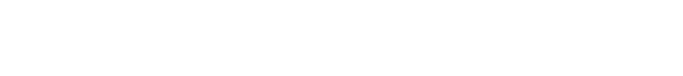

ard

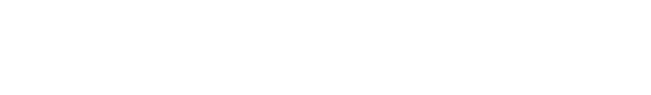

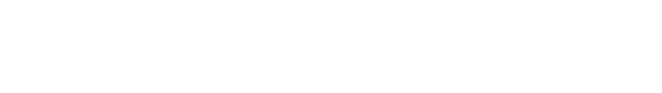

(1)

(n)

(1)
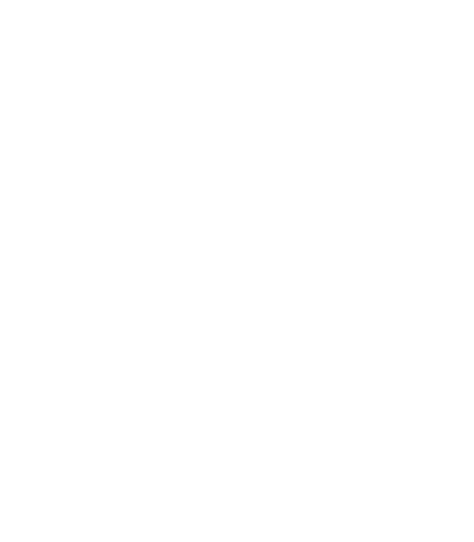

(1)

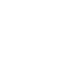


Figure

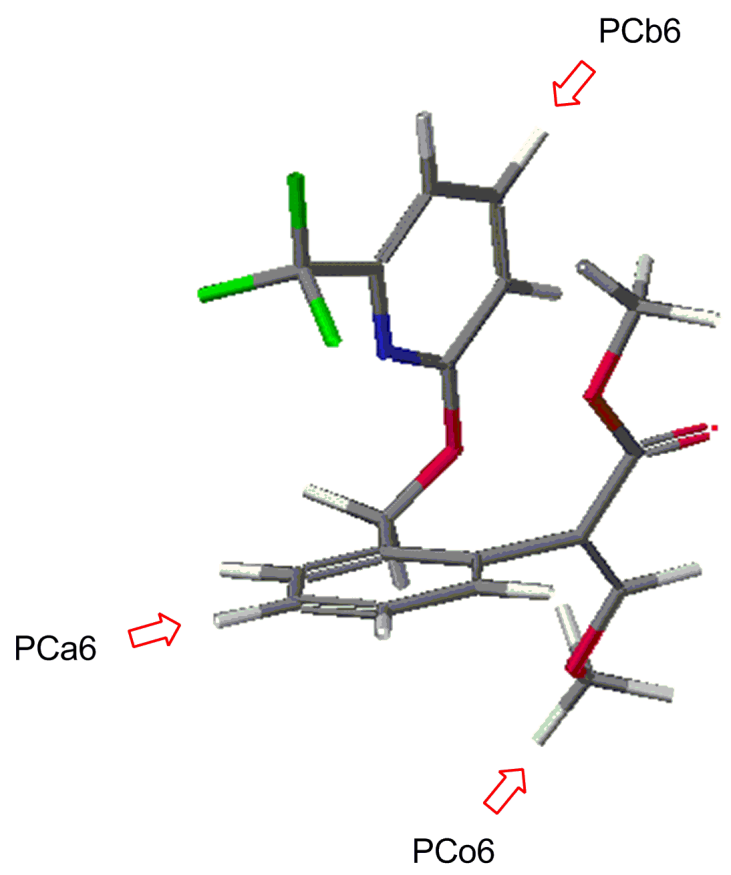

Figure 3, Parma et al. 

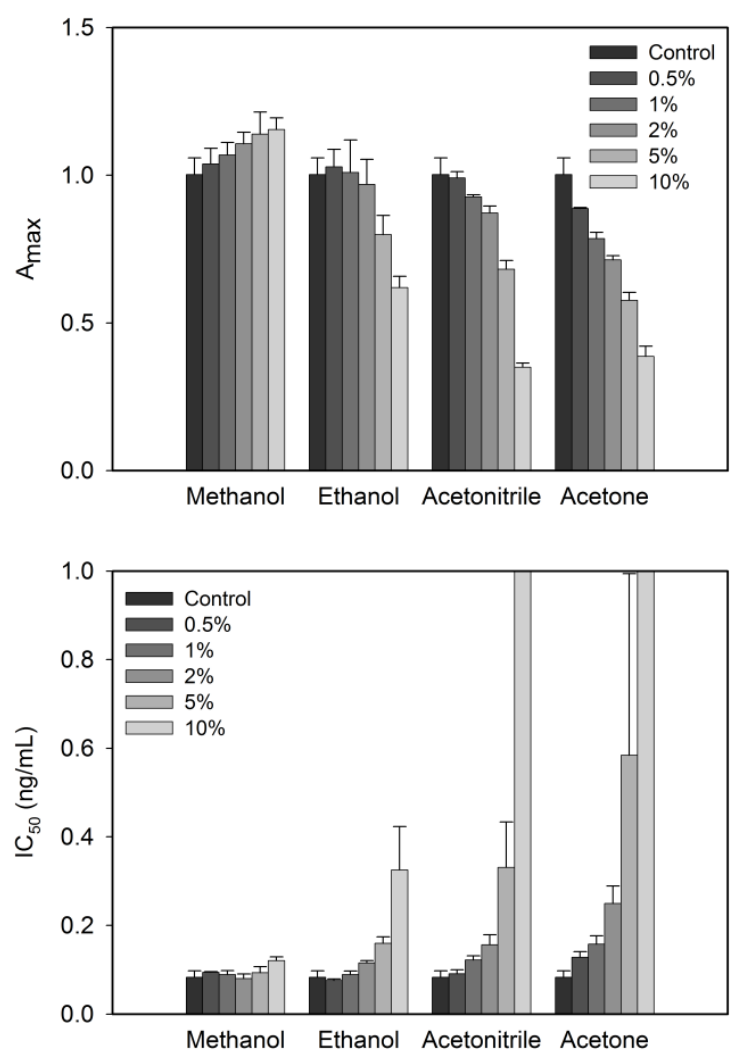

Figure 4, Parra et al. 


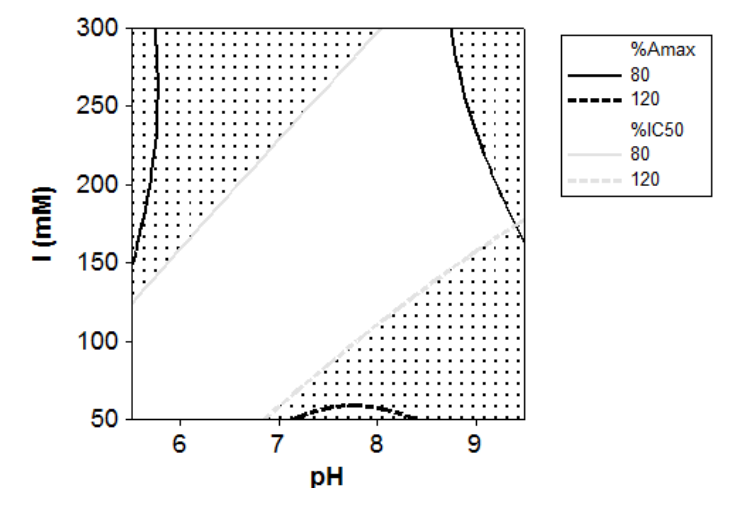

Figure 5, Parra et al.

Figure

Figure 5, Parra et al.

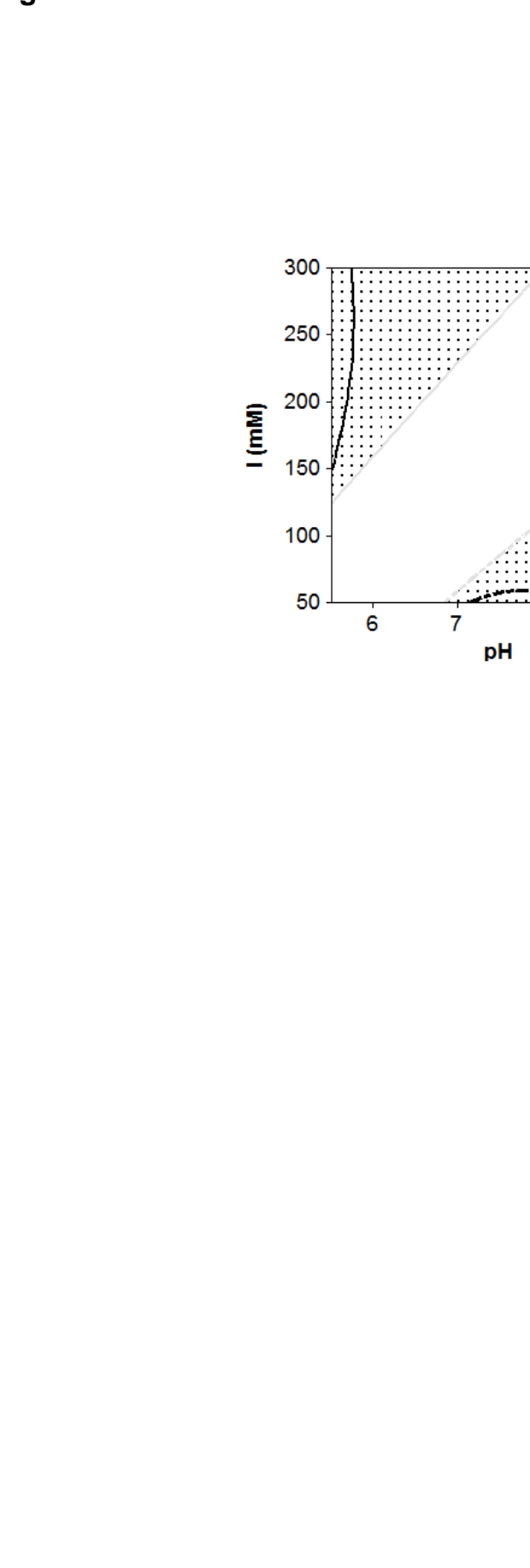

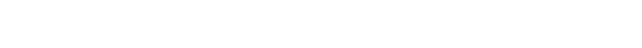

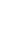

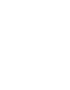

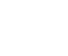

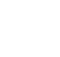

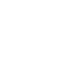

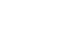

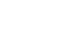

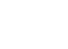

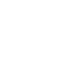
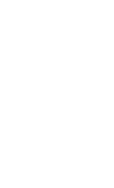

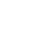
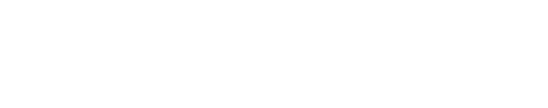


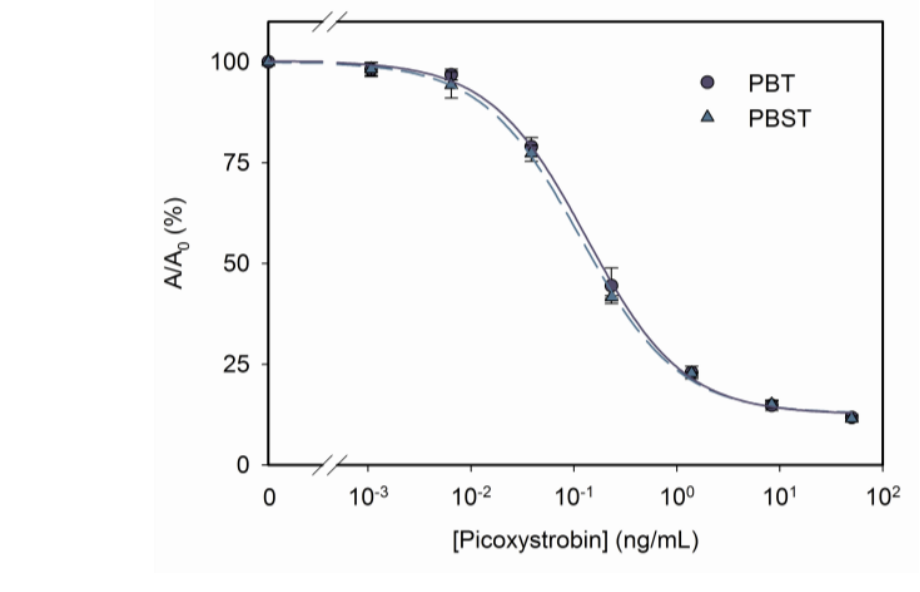

Figure 6, Parra et al.

[Picoxystrobin] (ng/mL)

Figure 6, Parra et al.

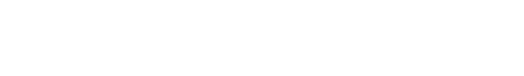

.

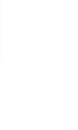

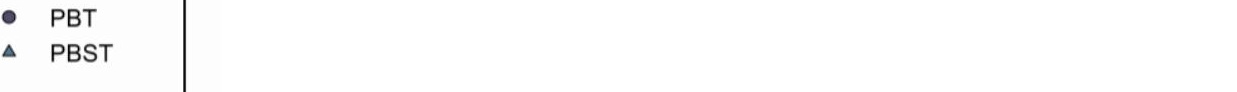




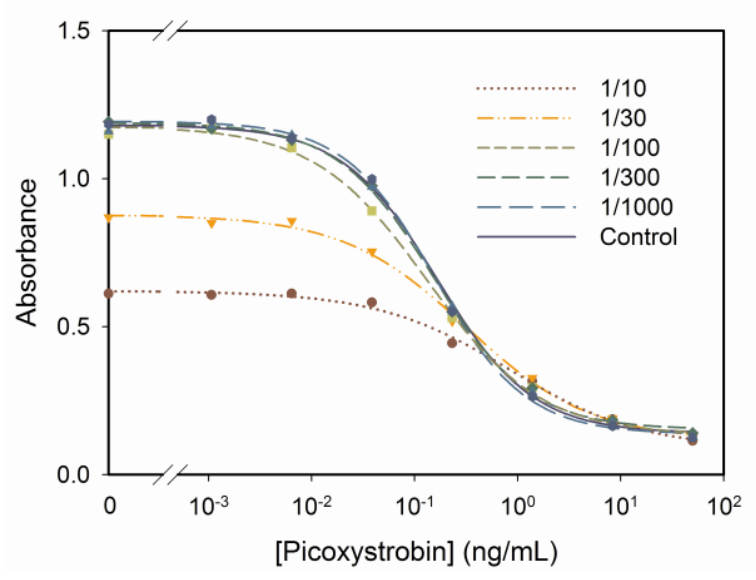

Figure 7, Parra et al. 
Table 1

Structure of PC and the synthetic haptens

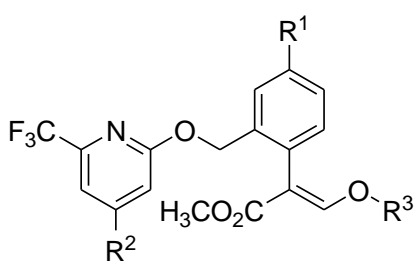

\begin{tabular}{llll}
\cline { 2 - 4 } & $\mathrm{R}^{1}$ & $\mathrm{R}^{2}$ & $\mathrm{R}^{3}$ \\
\hline $\mathrm{PC}$ & $\mathrm{H}$ & $\mathrm{H}$ & $\mathrm{CH}_{3}$ \\
$\mathrm{PCa6}(\mathbf{1})$ & $\left(\mathrm{CH}_{2}\right)_{5} \mathrm{CO}_{2} \mathrm{H}$ & $\mathrm{H}$ & $\mathrm{CH}_{3}$ \\
$\mathrm{PCb} 6(2)$ & $\mathrm{H}$ & $\left(\mathrm{CH}_{2}\right)_{5} \mathrm{CO}_{2} \mathrm{H}$ & $\mathrm{CH}_{3}$ \\
PCo6 (3) & $\mathrm{H}$ & $\mathrm{H}$ & $\left(\mathrm{CH}_{2}\right)_{5} \mathrm{CO}_{2} \mathrm{H}$ \\
\hline
\end{tabular}


Table 2

Characterization of anti-PC pAbs by checkerboard direct competitive assays ${ }^{a}$.

\begin{tabular}{|c|c|c|c|c|c|c|c|c|c|}
\hline \multirow[b]{2}{*}{$\begin{array}{l}\text { Immunizing } \\
\text { hapten }\end{array}$} & \multirow[b]{2}{*}{$\begin{array}{l}\text { HRP } \\
\text { tracer }\end{array}$} & \multicolumn{4}{|l|}{ Rabbit \#1 } & \multicolumn{4}{|l|}{ Rabbit \#2 } \\
\hline & & $\begin{array}{l}\text { pAb dilution } \\
\left(\times 10^{3}\right)\end{array}$ & $\begin{array}{l}\text { [Tracer] } \\
\text { (ng/mL) }\end{array}$ & $A_{\max }$ & $\begin{array}{l}\mathrm{IC}_{50} \\
(\mathrm{ng} / \mathrm{mL})\end{array}$ & $\begin{array}{l}\text { pAb dilution } \\
\left(\times 10^{3}\right)\end{array}$ & $\begin{array}{l}\text { [Tracer] } \\
(\mathrm{ng} / \mathrm{mL})\end{array}$ & $A_{\max }$ & $\begin{array}{l}\mathrm{IC}_{50} \\
(\mathrm{ng} / \mathrm{mL})\end{array}$ \\
\hline PCa6 & $\begin{array}{l}\text { PCa6 } \\
\text { PCb6 } \\
\text { PCo6 }\end{array}$ & $\begin{array}{l}1 \\
1 \\
1\end{array}$ & $\begin{array}{l}1000 \\
1000 \\
1000\end{array}$ & $\begin{array}{l}1.02 \\
-\mathrm{b} \\
-\end{array}$ & $\begin{array}{l}36.88 \\
-\end{array}$ & $\begin{array}{l}30 \\
1 \\
1\end{array}$ & $\begin{array}{l}30 \\
1000 \\
100\end{array}$ & $\begin{array}{l}1.09 \\
- \\
0.98\end{array}$ & $\begin{array}{l}2.50 \\
- \\
1.40\end{array}$ \\
\hline PCb6 & $\begin{array}{l}\text { PCa6 } \\
\text { PCb6 } \\
\text { PCo6 }\end{array}$ & $\begin{array}{l}1 \\
30 \\
1\end{array}$ & $\begin{array}{l}1000 \\
30 \\
1000\end{array}$ & $\begin{array}{l}- \\
1.07 \\
-\end{array}$ & $\begin{array}{l}- \\
1.51 \\
-\end{array}$ & $\begin{array}{l}1 \\
10 \\
1\end{array}$ & $\begin{array}{l}1000 \\
300 \\
1000\end{array}$ & $\begin{array}{l}- \\
0.84 \\
-\end{array}$ & $\begin{array}{l}- \\
2.83 \\
-\end{array}$ \\
\hline PCo6 & $\begin{array}{l}\text { PCa6 } \\
\text { PCb6 } \\
\text { PCo6 }\end{array}$ & $\begin{array}{l}1 \\
1 \\
3\end{array}$ & $\begin{array}{l}1000 \\
1000 \\
300\end{array}$ & $\begin{array}{l}1.38 \\
- \\
0.84\end{array}$ & $\begin{array}{l}0.15 \\
- \\
0.48\end{array}$ & $\begin{array}{l}1 \\
1 \\
3\end{array}$ & $\begin{array}{l}300 \\
1000 \\
100\end{array}$ & $\begin{array}{l}0.86 \\
- \\
0.81\end{array}$ & $\begin{array}{l}3.05 \\
- \\
0.62\end{array}$ \\
\hline
\end{tabular}

${ }^{a}$ A capture antibody solution was employed at $3000 \mathrm{ng} / \mathrm{mL} .{ }^{\mathrm{b}}$ The maximum signal was below 0.8 under these conditions. 
Table 3

Characterization of anti-PC pAbs by checkerboard indirect competitive assays.

\begin{tabular}{|c|c|c|c|c|c|c|c|c|c|}
\hline \multirow[b]{2}{*}{$\begin{array}{l}\text { Immunizing } \\
\text { hapten }\end{array}$} & \multirow[b]{2}{*}{$\begin{array}{l}\text { OVA } \\
\text { conjugate }\end{array}$} & \multicolumn{4}{|l|}{ Rabbit \#1 } & \multicolumn{4}{|l|}{ Rabbit \#2 } \\
\hline & & $\begin{array}{l}\text { pAb dilution } \\
\left(\times 10^{3}\right)\end{array}$ & $\begin{array}{l}\text { [Coating] } \\
(\mathrm{ng} / \mathrm{mL})\end{array}$ & $A_{\max }$ & $\begin{array}{l}\mathrm{IC}_{50} \\
(\mathrm{ng} / \mathrm{mL})\end{array}$ & $\begin{array}{l}\text { pAb dilution } \\
\left(\times 10^{3}\right)\end{array}$ & $\begin{array}{l}\text { [Coating] } \\
(\mathrm{ng} / \mathrm{mL})\end{array}$ & $A_{\max }$ & $\begin{array}{l}\mathrm{IC}_{50} \\
(\mathrm{ng} / \mathrm{mL})\end{array}$ \\
\hline PCa6 & $\begin{array}{l}\text { PCa6 } \\
\text { PCb6 } \\
\text { PCo6 }\end{array}$ & $\begin{array}{l}10 \\
3 \\
3\end{array}$ & $\begin{array}{l}1000 \\
1000 \\
1000\end{array}$ & $\begin{array}{l}1.32 \\
1.36 \\
1.41\end{array}$ & $\begin{array}{l}17.04 \\
-\mathrm{a} \\
1.91\end{array}$ & $\begin{array}{l}10 \\
3 \\
30\end{array}$ & $\begin{array}{l}100 \\
100 \\
1000\end{array}$ & $\begin{array}{l}1.22 \\
1.07 \\
1.34\end{array}$ & $\begin{array}{l}9.46 \\
- \\
2.46\end{array}$ \\
\hline $\mathrm{PCb} 6$ & $\begin{array}{l}\mathrm{PCa} 6 \\
\mathrm{PCb} 6 \\
\mathrm{PCo} 6\end{array}$ & $\begin{array}{l}3 \\
30 \\
10\end{array}$ & $\begin{array}{l}1000 \\
100 \\
1000\end{array}$ & $\begin{array}{l}1.35 \\
1.00 \\
1.50\end{array}$ & $\begin{array}{l}1.80 \\
1.18 \\
2.53\end{array}$ & $\begin{array}{l}10 \\
30 \\
30\end{array}$ & $\begin{array}{l}1000 \\
100 \\
1000\end{array}$ & $\begin{array}{l}1.25 \\
0.91 \\
1.09\end{array}$ & $\begin{array}{l}1.40 \\
1.07 \\
1.18\end{array}$ \\
\hline PCo6 & $\begin{array}{l}\mathrm{PCa} 6 \\
\mathrm{PCb} 6 \\
\mathrm{PC} 06\end{array}$ & $\begin{array}{l}10 \\
10 \\
10\end{array}$ & $\begin{array}{l}1000 \\
1000 \\
100\end{array}$ & $\begin{array}{l}1.25 \\
1.47 \\
1.09\end{array}$ & $\begin{array}{l}0.25 \\
2.68 \\
0.48\end{array}$ & $\begin{array}{l}30 \\
30 \\
10\end{array}$ & $\begin{array}{l}1000 \\
1000 \\
100\end{array}$ & $\begin{array}{l}0.88 \\
0.99 \\
0.93\end{array}$ & $\begin{array}{l}3.53 \\
1.10 \\
0.81\end{array}$ \\
\hline
\end{tabular}

${ }^{a}$ No inhibition was observed. 
Table 4

Effect of the hapten-to-protein MR of OVA-PCa6 conjugate over the inhibition curve parameters obtained with pAb rPCo6\#1.

\begin{tabular}{lllllll}
\hline $\begin{array}{l}\text { OVA-PCa6 } \\
\text { conjugate }\end{array}$ & $\begin{array}{l}\text { Coating] } \\
(\mathrm{ng} / \mathrm{mL})\end{array}$ & $\begin{array}{l}\text { rPCo6\#1 dilution } \\
\left(\times 10^{3}\right)\end{array}$ & $A_{\max }$ & Slope & $\begin{array}{l}\mathrm{IC}_{50} \\
(\mathrm{ng} / \mathrm{mL})\end{array}$ & $\mathrm{A}_{\min }$ \\
\hline MR 0.6 & 100 & 1 & 0.37 & 1.36 & 0.32 & 0.27 \\
& 300 & 1 & 0.66 & 1.50 & 0.25 & 0.30 \\
MR 3.0 & 1000 & 3 & 0.67 & 1.16 & 0.13 & 0.19 \\
& 100 & 1 & 0.96 & 1.31 & 0.42 & 0.27 \\
MR 6.0 & 300 & 3 & 0.95 & 1.09 & 0.15 & 0.16 \\
& 1000 & 10 & 1.01 & 1.06 & 0.10 & 0.13 \\
& 100 & 1 & 1.42 & 1.51 & 0.47 & 0.23 \\
& 300 & 3 & 0.81 & 1.27 & 0.40 & 0.25 \\
\hline
\end{tabular}


Table 5

Recoveries from PC-spiked soybean sprouts by the proposed cELISA procedure ( $\% \pm s, n=3)$.

\begin{tabular}{llll}
\hline $\begin{array}{l}\text { Spiked PC } \\
(\mu \mathrm{g} / \mathrm{kg})\end{array}$ & Dilution & & \\
\cline { 2 - 4 } & $1 / 100$ & $1 / 300$ & $1 / 1000$ \\
\hline 5 & $100 \pm 11$ & $-\mathrm{a}$ & - \\
10 & $106 \pm 13$ & $108 \pm 15$ & - \\
50 & $110 \pm 10$ & $118 \pm 19$ & $104 \pm 3$ \\
100 & $97 \pm 8$ & $117 \pm 19$ & $114 \pm 13$ \\
500 & - & $98 \pm 7$ & $117 \pm 13$ \\
1000 & - & - & $112 \pm 19$ \\
\hline
\end{tabular}

${ }^{a}$ Out of the linear range. 